\title{
Detection of K19 mRNA Compared with Tumour Markers in Peripheral Blood from Breast Cancer Patients
}

\author{
Yunus A. Luqmani ${ }^{a, b, c}$ Labiba Temmim $^{b}$ Sharon Lobo ${ }^{a}$ Manoj Mathewa,b \\ Medhat Oteifa ${ }^{c}$ Majda Alic Abdul-Hamid Parkarc \\ aDepartment of Medical Laboratory Sciences, Faculty of Allied Health Sciences; bDepartment of Pharmaceutical \\ Chemistry, Faculty of Pharmacy, Kuwait University, and 'Department of Pathology, Kuwait Cancer Control Center, \\ Kuwait
}

\section{Key Words}

Breast cancer $\cdot$ Micrometastases $\cdot$ Polymerase chain reaction $\cdot$ Keratin $19 \cdot$ Carcino-embryonic antigen . CA15.3

\begin{abstract}
Objectives: A rise in peripheral blood of the glycoproteins carcino-embryonic antigen (CEA) and CA15.3 may be indicative of a subsequent clinical relapse and provides a useful adjunct in the management of metastatic breast cancer. We wished to study the relationship of these tumour markers with the expression of keratin 19 (K19) mRNA as a marker of epithelial cancer cells in periodic blood samples taken from patients undergoing postoperative therapy. Methods: CEA and CA15.3 were measured by radio-immunoassay while K19 mRNA was assessed by gel electrophoretic separation after a 40 cycle polymerase chain reaction amplification. Results: Analysis of 395 samples (regardless of patient) showed concurrence in the detection of K19 and CEA and CA15.3 (using positivity cut-offs of $3.2 \mathrm{ng} / \mathrm{ml}$ and $32 \mathrm{U} / \mathrm{l}$, respectively) in $<20 \%$ of cases that were $\mathrm{K} 19+$ and in $>80 \%$ for samples that were K19-. The frequency of CEA and CA15.3 positivity was related to the amount of K19 product. For 65 patients with 2-3 samples collected at 6 monthly intervals, we observed complete agreement for
\end{abstract}

detection of these markers (at each occasion) in about $30 \%$ of cases only. Conclusions: These discrepancies may be due partly to the currently qualitative nature of the K19 assessment and emphasize the need for quantification of this but may also reflect a difference in the source of the signals, i.e. K19 originating from circulating cells and CEA/CA15.3 shed from solid tumour deposits. It is likely that K19 detection is more sensitive, but it is less certain which of these markers reflects a significant systemic tumour load and hence is of greater value in predicting relapse.

Copyright $@ 2001$ S. Karger AG, Base

\section{Introduction}

Monitoring of disease recurrence in breast cancer patients currently relies upon periodic clinical investigations such as scintigraphy, which most likely reveal tumour burden at an already advanced stage, diminishing the effectiveness of subsequent chemotherapeutic intervention. Radio-immunoassays have been developed to measure circulating glycoproteins such as carcino-embryonic antigen (CEA) and CA15.3 as cancer-associated markers $[1,2]$ and are therefore possible earlier indicators of regrowing metastatic tumours [3-6]. Although these often correlate well with the occurrence of metastatic disease,

\begin{tabular}{ll}
\hline KARGER & ( ) 2001 S. Karger AG, Basel \\
Fax +4161306 1234 & 1011-7571/01/0101-0048\$17.50/0 \\
$\begin{array}{l}\text { E-Mail karger@karger.ch } \\
\text { www.karger.com }\end{array}$ & $\begin{array}{l}\text { Accessible online at: } \\
\text { www.karger.com/journals/mpp }\end{array}$
\end{tabular}

Dr. Y.A. Luqmani

Department of Pharmaceutical Chemistry, Faculty of Pharmacy

Kuwait University, PO Box 24923

Safat 13110 (Kuwait)

Fax+965 5347926, E-Mail yunus@hsc.kuniv.edu.kw 
they are still widely regarded as a useful adjunct to imaging/bone scans and not as a replacement for them [7]. Although both CA15.3 and to a lesser extent CEA are often found to be elevated prior to clinical detection of recurrence [5], this is only true of a part of the patients. These markers may be inadequate for occult micrometastases which have been detected by immunohistochemical methods in lymph nodes and bone marrow and which appear to have prognostic significance $[8,9]$. The presence of circulating cancer cells has been inferred by the detection of mRNA encoding epithelial specific proteins [10-16] following polymerase chain reaction (PCR) amplification of extracted mRNA. PCR enables detection of just a few cells containing the expressed marker and has considerable advantages over immunohistochemical methods. Cytokeratin 19 (K19) in particular has received much attention since the initial studies demonstrating its usefulness in detecting residual breast cancer [10, 17]. Detection sensitivities down to 1 cancer cell equivalent spiked in $10^{5}-10^{7}$ mononuclear cells have been reported $[13,18-20]$ similar to reports for other genes [8]. The wide variations in reported sensitivity of these assays reflects the diversity of cell lines used to provide the K19 signal, differences in cell counting methods, variability in RNA extraction, cDNA synthesis and PCR efficiency, heterogeneity of marker expression and detection methods. 'Illegitimate' transcription of K19 originating from non-epithelial haematopoietic cells [21] could also pose problems when operating at the lower limits of detection; amplification from processed K19 pseudogenes [22, 23] may also provide an additional signal from contaminant DNA present in RNA preparations, although this can be avoided by an appropriate primer design. Thus, an increasing number of reports have noted K19 signals from blood taken from healthy volunteers $[15,16,19,24]$, causing increasing concern over its suitability as a reliable indicator of micrometastases.

In this study, we examined the correlation between K19 and the soluble tumour markers CEA/CA15.3 commonly used to monitor patients for metastatic disease.

\section{Materials and Methods}

\section{Patients}

This study was performed on 329 consecutive patients who had undergone surgery for breast cancer and who were attending the Breast Clinic at the Kuwait Cancer Control Center for postsurgical follow-up from 1995 to 1998 . Blood samples were taken during their periodic visits for routine analysis, which included tumour markers CEA and CA15.3. Additional samples were taken when possible for measurement of K19 which, due to social and other constraints, were more sporadic than was originally intended. Patient attendance varied greatly according to their clinical circumstances. In total we obtained 1,685 samples for CEA and CA15.3 measurement and 530 samples for determination of K19; of these, 395 were taken either on the same occasion or within 1 week of the sample assayed for CEA/ CA15.3. This was considered to be simultaneous.

\section{Tissue Culture}

The MCF7 breast cancer cell line was obtained from Charing Cross Hospital (London, UK) and was originally from the American Type Culture Collection (Rockville, Md., USA) and maintained in RPMI-1640 medium supplemented with 10\% fetal calf serum, glutamine and antibiotics. Cells were harvested by trypsinisation and, after washing in PBS, resuspended in medium and counted using a haemocytometer.

\section{Cell Separation and RNA Extraction}

Peripheral blood samples $(10-15 \mathrm{ml})$ from breast cancer patients and healthy volunteers were collected in EDTA vacutainers and subjected to density gradient cell separation using Lymphoprep as previously described [13]. The final lymphocyte fraction was resuspended in RNAZol for immediate RNA extraction or after storage at $-20^{\circ} \mathrm{C}[13]$.

\section{cDNA Synthesis and PCR Amplification}

RNA $(4 \mu \mathrm{g})$ was converted into cDNA using SuperScript II RNaseH- Reverse transcriptase (Gibco-BRL, UK) and random hexamers (Pharmacia, Sweden; $200 \mathrm{ng}$ ) in a 20- $\mu \mathrm{l}$ reaction mix containing $50 \mathrm{~m} M$ Tris- $\mathrm{HCl}, \mathrm{pH} 8.3,75 \mathrm{~m} M \mathrm{KCl}, 3 \mathrm{~m} M \mathrm{MgCl}_{2}, 1 \mathrm{~m} M$ each of dATP, dCTP, dGTP and dTTP (Pharmacia, Sweden) and $5 \mathrm{mM}$ dithiothreitol. Following incubation at $42^{\circ} \mathrm{C}$ for $1 \mathrm{~h}$, the mixture was heated to $95^{\circ} \mathrm{C}$ for $10 \mathrm{~min}$, snap cooled and stored at $-20^{\circ} \mathrm{C}$. Controls excluding RNA were run each time. For amplification, $4 \mu \mathrm{l}$ of the cDNA was added to a $50-\mu 1$ reaction mix containing 1 unit AmpliTaq DNA polymerase (Perkin Elmer Cetus, USA), $50 \mathrm{mM}$ $\mathrm{KCl}, 10 \mathrm{~m} M$ Tris- $\mathrm{HCl}, \mathrm{pH} 8.3,2.5 \mathrm{~m} M \mathrm{MgCl}_{2}, 200 \mu M$ dNTPs and 200 ng each of the K19 primers K9, which has a non-homologous $5^{\prime}$ taq sequence (italicised) designed for use in fluorochrome detection ( $g$ ggacgcCGAGCAGAACCGGAAGGATGCTGAA), and K6 (TGAGCCGCTGGTACTCCTGAT), and (as a reference gene) the glyceraldehyde phosphate dehydrogenase primers GAP-1 and -2 (TCCCATCACCATCTTCCA and CATCACGCCACAGTTTCC). After an initial denaturation step at $94^{\circ} \mathrm{C}$ for $3 \mathrm{~min}$, cycling parameters were denaturation at $94^{\circ} \mathrm{C}$ for $30 \mathrm{~s}$, annealing at $55^{\circ} \mathrm{C}$ for $20 \mathrm{~s}$ and extension at $72^{\circ} \mathrm{C}$ for $30 \mathrm{~s}$ repeated for 40 cycles for the standard conditions, followed by a final extension of $10 \mathrm{~min}$. In experiments examining sensitivity, a nested PCR procedure was used; in this case, the first PCR was performed as above but using K19 primers K8 (GTGACATGCGAAGCCAATATGAGG) and K2 (ATCTTCCTGTCCCTCGAGCAGG) and GAP-1 and -2 . An aliquot $(1 \mu \mathrm{l})$ from this reaction was used as a template in a second PCR containing primers $\mathrm{K} 9$ and $\mathrm{K} 6$ and GAP-1 and -2, performed as above. Appropriate controls excluding template DNA as well as reagent blanks were included in each run. Primers were designed to minimise homology with published pseudogene sequences. Random samples were sequenced using the dideoxy termination method (at Oswel Research, Southampton, UK) to confirm their identity as the expected mRNA-derived K19 sequence and there was no evidence of a pseudogene DNA-derived sequence being amplified. Products were 


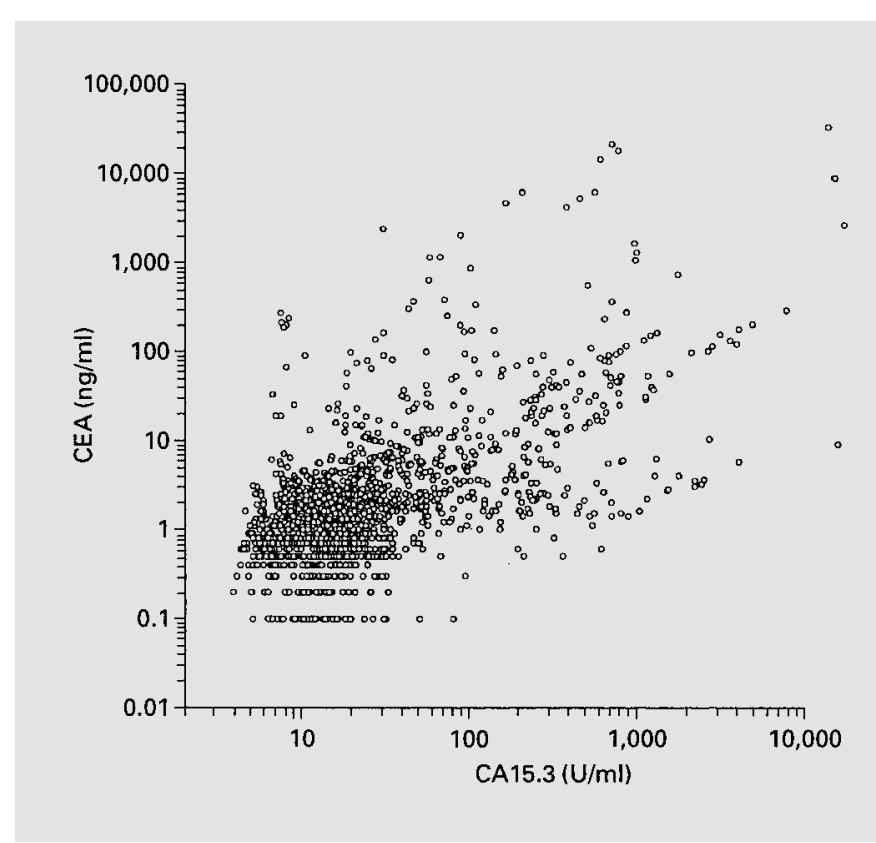

Fig. 1. Relationship between CEA and CA15.3 measured by radioimmunoassay in 1,685 serum samples from 329 breast cancer patients.

electrophoresed on $0.8 \%$ agarose gels and visualised with ethidium bromide under UV light. Where applicable, band intensity was quantified by means of a DNA gel documentation system and given an arbitrary intensity assignment of,,,- \pm+++ or +++ , taking into account the GAP signal. For positive controls, DNA of recombinant plasmids containing GAP or K19 cDNA sequences was amplified [13].

\section{Sensitivity Assays}

Cell Number. Experiments were performed in which RNA was prepared from aliquots of normal lymphocytes $\left(6 \cdot 10^{6}\right)$ spiked with 5-500 MCF7 cells. Following conversion to cDNA, K19 was amplified by 40 cycles with $\mathrm{K} 8 / \mathrm{K} 2$ primers followed by a nested PCR with $\mathrm{K} 9 / \mathrm{K} 6$ for 20 cycles.

Amount of RNA. Separately extracted lymphocyte RNA $(2 \mu \mathrm{g})$ was mixed with $1 \mathrm{pg}$ to $100 \mathrm{ng}$ MCF7 RNA and converted to cDNA. This was subjected to amplification as above and also with $\mathrm{K} 9 / \mathrm{K} 6$ directly.

\section{Determination of CEA and CA15.3}

These proteins were determined in fresh serum samples using the automated microparticle enzyme immunoassay system from Abbott Laboratories (Chicago, Ill., USA) following the manufacturer's protocol. For purposes of analysis, cut-off points recommended by Abbott (similar to widely accepted values) were used to indicate positivity: $3.2 \mathrm{ng} / \mathrm{ml}$ for CEA and $30 \mathrm{U} / \mathrm{ml}$ for CA15.3.

\section{Statistical Analyses}

Data were analysed using the SPSS statistical computer software package. The relationship between CEA and CA15.3 (both of which showed a skewed non-normal distribution) was examined using Spearman's correlation for non-parametric data. The $\chi^{2}$ test was used to test for association between CEA and K19 and CA15.3 and K19 using the cut-off values given above to divide patients into positive and negative groups. For K19, a PCR product visible by ethidium bromide staining was taken as indicative of positivity.

\section{Results}

\section{Measurement of CEA and CA15.3}

Periodic blood samples were collected from 329 patients during the course or their postsurgical follow-up without regard to their therapy. Due to individual circumstances this ranged from 1 to 22 samples per patient. The serum levels of CEA and CA15.3 were simultaneously determined. Figure 1 illustrates the relationship between these proteins. Although there was a statistically significant relationship between these markers $(\mathrm{p}<0.0001)$ presumably due to the large sample size $(n=1,685)$, the low correlation coefficient $\left(r_{s}=0.41\right)$ is indicative of a rather moderate correlation among a high proportion of samples. Using the cut-off values to determine positivity, about $89 \%$ of CEA- samples were also CA15.3-; only $60 \%$ of CEA+ samples were also CA15.3+.

\section{K19 Determinations, PCR Sensitivity Tests}

Preliminary experiments with various primer combinations and cycling parameters were performed to determine PCR sensitivity in terms of the number of cancer cells detectable in a given background of lymphocytes. With nested PCR (40 cycles K8/K2 + 20 cycles K9/K6), we detected a K19 signal from $5 \mathrm{MCF} 7$ cells $/ 6 \cdot 10^{6}$ mononuclear cells. In terms of the amount of starting RNA used to make cDNA, a signal from $10 \mathrm{ng}$ could be detected after the first PCR, and from $10 \mathrm{pg}$ after nested PCR. If K9/K6 were used in a single-round PCR only, a signal was consistently seen from $1 \mathrm{ng}$ and frequently from $100 \mathrm{pg}$ (fig. 2). On the basis of cell number, the sensitivity was $1-5 / 5 \cdot 10^{5}$ cells. An attempt was then made to amplify K19 from blood samples taken from 17 healthy volunteers. No signal was detected after the first PCR with either primer set. After nested PCR, K19 product was found in 6 cases (data not presented).

\section{Potential Contamination from Skin Cells}

From another 7 volunteers, using the same vacutainer method of phlebotomy, an initial $1 \mathrm{ml}$ of blood by venepuncture was taken, the vacutainer was removed and a second one inserted; more blood was taken into this one 

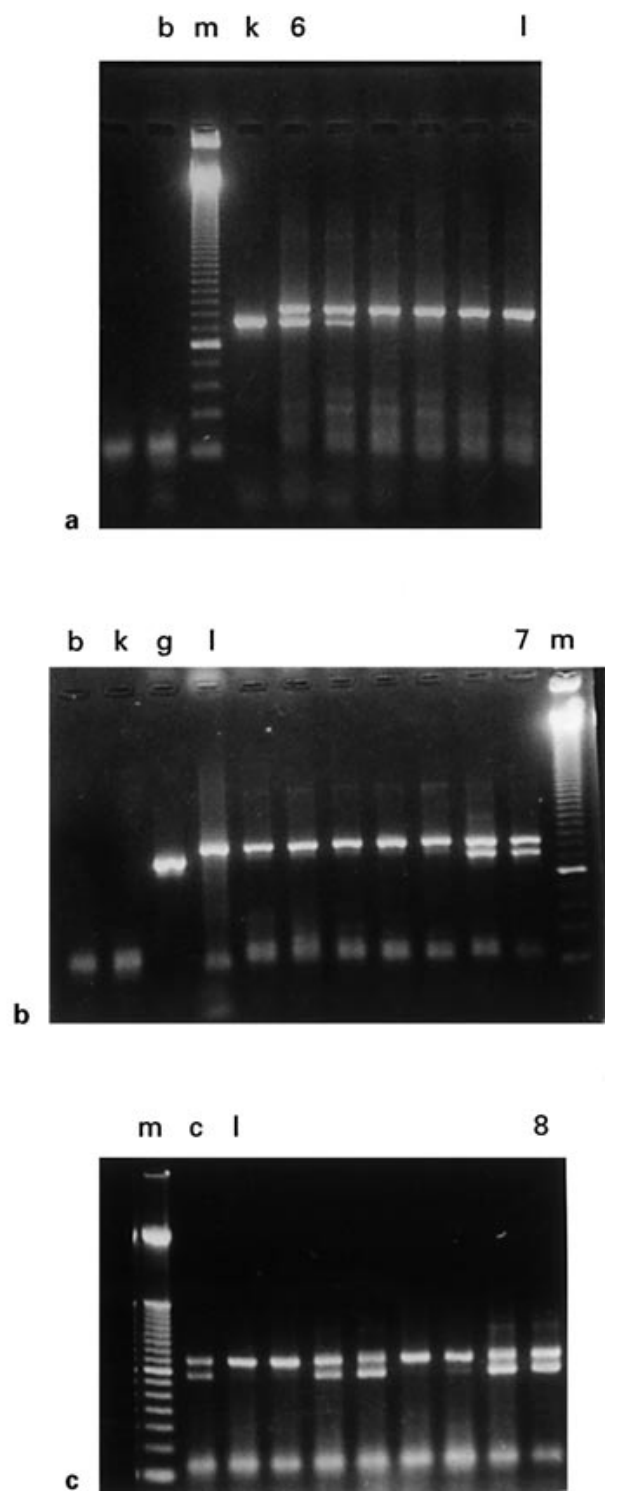

Fig. 2. Sensitivity analysis was performed by nested PCR as described in the Methods either by amplifying $4 \mu \mathrm{g}$ RNA extracted from $6 \cdot 10^{6}$ lymphocytes spiked with $0,0,5,5,50$ and 500 MCF7 cells (a, lanes 1-6) or $2 \mu \mathrm{g}$ lymphocyte RNA mixed with $0,0,1,5,5$, 10 and 100 pg MCF7 RNA (b, lanes 1-7). Single-round PCR with $\mathrm{K} 9 / \mathrm{K} 6$ was also performed on $2 \mu \mathrm{g}$ lymphocyte RNA mixed with 10 , 10, 100, 100,100,100, 1,000 and 1,000 pg MCF7 RNA (c, lanes $1-8)$. PCR products were electrophoresed through $0.8 \%$ agarose gels and stained with ethidium bromide. Upper bands correspond to the 379-bp GAP product and lower bands to the 326-bp K19 product. Lanes labelled $\mathrm{m}$ have a 50-bp ladder from Gibco-BRL; b are negative controls; $\mathrm{k}$ are positive K19 plasmid controls; $\mathrm{g}$ is a GAP plasmid control; $\mathrm{c}$ is a control from a mixture of GAP and K19 plasmids.

Circulating K19, CEA and CA15.3 in Breast Cancer
Table 1. Correlation between K19 and CEA/CA15.3 in peripheral blood of breast cancer patients

\begin{tabular}{|c|c|c|c|}
\hline & \multicolumn{2}{|c|}{ K19 mRNA } & \multirow[t]{2}{*}{$\mathrm{p}$} \\
\hline & - & + & \\
\hline CEA- & 125 & 207 & 0.4539 \\
\hline CEA+ & 20 & 43 & \\
\hline CA15.3- & 124 & 215 & 0.4531 \\
\hline CA15.3+ & 24 & 32 & \\
\hline
\end{tabular}

K19 was determined by PCR and CEA/CA15.3 by radio-immunoassay. Positivity was based on criteria given in the Methods. The $\chi^{2}$ test was used to test for significant difference. Patients were divided into positive and negative groups for CEA and CA15.3 to determine whether there was any correlation with K19 positivity.

while the needle remained in position within the vein. No K19 product was seen after 40 cycles with K9/K6 alone. By nested PCR, a signal from 7 individuals was observed from their first blood sample but not from the second and from one in both samples (data not shown).

\section{K19 Detection in Patient Blood Samples}

In order to avoid such 'false-positive' results, the procedure involving a single round of PCR using K9/K6 primers for the patient study was adopted. This meant that the threshold value was about $100 \mathrm{pg}$ cancer-derived RNA or about 50 cancer cells in the blood samples. To ensure that PCR products did not originate from any contaminating DNA in the RNA preparations, two types of controls were also performed with each RT-PCR run, one in which the reverse transcriptase was omitted during the cDNA synthesis reaction and one where the RNA preparation had been treated with deoxyribonuclease. Only in the latter case was a specific K19 PCR product obtained. The K19 primers were also designed to minimise sequence homology with the known K19 pseudogenes.

Although 530 samples for K19 PCR were processed, the results from only 395 of these were analysed as it was not possible to obtain a simultaneous measurement for CEA/CA15.3 for the other 135. If any K19 PCR product visible as an ethidium-bromide-stained band upon electrophoresis was considered positive, then there was no association with either CEA or CA15.3. Using the standard cut-offs for CEA/CA15.3, there was $<20 \%$ agreement for $\mathrm{K} 19+$ cases but $>80 \%$ agreement for K19- cases. Using the $\chi^{2}$ test, no overall significant association was seen between these groups (table 1). If the K19 signal was

Med Principles Pract 2001;10:48-54 


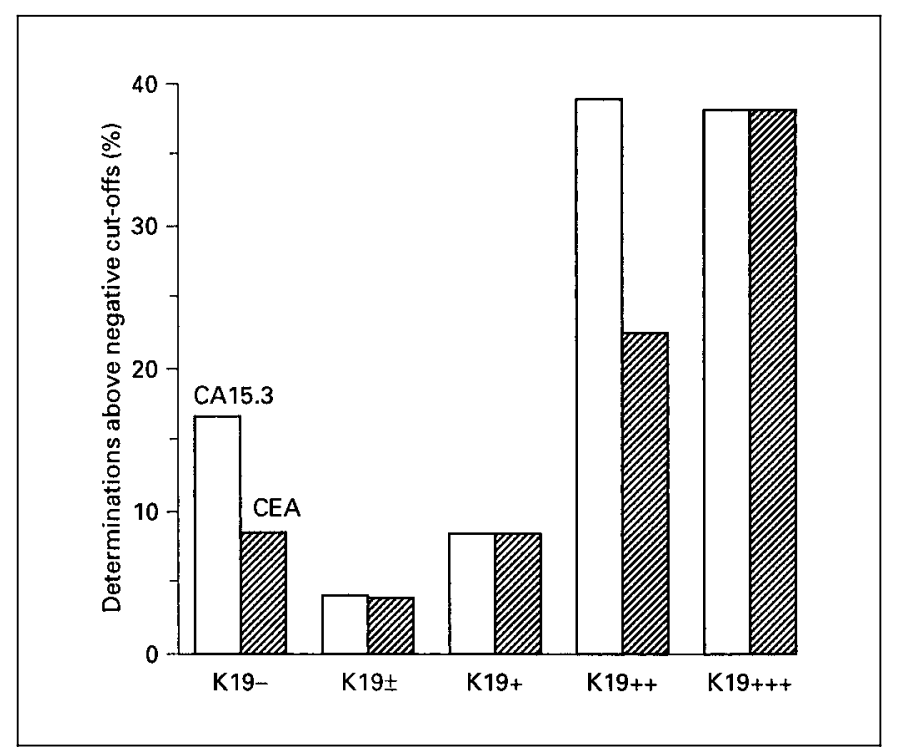

Fig. 3. Single-round 40-cycle PCR with K9/K6 was performed on RNA extracted from blood of breast cancer patients. Samples were categorised on the basis of K19 product band intensity from undetectable (-) to highly expressed (+++). Histograms show the percentage of samples which were positive for CEA and CA15.3 in each group.

assessed on the basis of band intensity (fig. 3), a greater proportion of samples was CEA/CA15.3+ as the level of $\mathrm{K} 19$ increased. However, even for samples with the highest K19 band intensity, only $40 \%$ of those were also positive for the tumour markers. Results for 65 patients were also analysed individually, where 3 samples collected at 6-month intervals were measured to determine whether the status of the tumour markers during this period coincided with K19 PCR product. Only in 20 patients (31\%) did all samples show consistent agreement (whether high or low) between K19 and CEA, and in 16 (25\%) between K19 and CA15.3. In 22 (CEA) and 26 (CA15.3) patients there was partial agreement with K19 for 1 or more of the 3 samples. In 23 patients there was complete discordance in the repeated samples for both markers.

The data from 119 patients whose earliest sample was K19+ and CEA/CA15.3- and from whom multiple samples for CEA/CA15.3 had been assayed over at least 12 months were also examined to determine the course of CEA/CA15.3. It was found that 20 patients became either CEA+ or CA15.3+ within several months of the positive K19 result, 65 remained negative and a further 34 remained negative even though repeat K19 measurements were positive.

\section{Discussion}

Detection of micrometastases has obvious clinical implications for the initial staging of apparently histologically node-negative breast cancer patients. Lack of specific cancer markers has led to evaluation of various epithelial specific proteins by immunohistochemistry or their mRNA transcripts by PCR amplification in lymph nodes, bone marrow and blood. Measurement of K19 by PCR [10, 13, 17] has received particular attention, with emphasis on establishing criteria for specificity and sensitivity and on achieving single cell detection [8]. The desire for extreme sensitivity (which can be manipulated by many factors) has resulted in the increasingly frequent observation of signals from samples taken from individuals without cancer [24-26]. The proffered explanation that this may be due to low-level ubiquitous transcription of all genes in all cells [27] does not account for non-detection of mRNA in normal blood under assay conditions claiming detection sensitivity down to 1 in $10^{7}$ cells. In contrast to previous findings [13], we observed that nested PCR resulted in amplification of K19 from normal blood, most likely due to greater efficiency in the enzymatic steps in our current procedure. Experiments in which an initial blood sample was compared with a subsequent one taken during the same bleeding suggest that skin cells may be the source of this K19 signal. In each positive case, it was the first sample (the most likely to be contaminated) that gave the K19 signal. Dingemans et al. [26], on the basis of similar experiments, concluded that haematopoietic rather than skin cell contamination was the explanation for their finding of more random positivity between first and second blood samples. This was the rationale for immunomagnetic cell selection [19] as an effective means of excluding non-epithelial cells prior to RNA extraction. Aihara et al. [20] also raised the issue of epidermal cell contamination; they reported 8/50 normal samples as K19 positive after nested PCR and advocated the practice of discarding the initial $1 \mathrm{ml}$ of collected blood. Interestingly, only $2 / 87$ samples from patients with gastric or pancreatic cancer showed positivity; who no 'illegitimate' signal from the other 85 ? Whatever its source, this low-level K19 expression is clearly random and will prove to be difficult to eliminate. It seems unwise to devise a routine procedure which not only operates at the limit of technical sensitivity but is subject to the slightest contamination. Such considerations have led to a criticism of the usefulness of K19 for the detection of an occult tumour [15]. It may be appropriate to establish a suitable thresh- 
old level (a common practice with other markers) which has clinical relevance.

K19 signals were compared with measurements of CEA and CA15.3 that are routinely performed during follow-up after breast surgery. The one-step PCR was adopted which detected approximately $100 \mathrm{pg}$ of cancer cell RNA (about 50 cells). When K19 was undetectable, CEA and CA15.3 were below their consensus cut-off levels for positivity in 19 and $83 \%$ of cases, respectively, a high rate of concordance. Where K19 was detected, frequency of CEA/CA15.3 positivity was approximately correlated to K19 band intensity, although only up to $40 \%$ of even the K19+++ cases were also positive for either CEA or CA15.3. Denis et al. [19] reported a similar lack of correlation in their examination of CEA (and CA19.9) in preoperative blood samples from patients with colorectal cancer; for K19- cases, CEA was also negative in 73\%, but in $\mathrm{K} 19+$ ones, it was only positive in $42 \%$. A recent report on mammoglobin, used as an alternative breast marker [28], also observed that CEA was negative in $84 \%$ of mammoglobin-negative cases but positive in only $50 \%$ of those that were mammoglobin positive. It is presumed that CEA/CA15.3 are released into the circulation having been shed from metastatic deposits either by active secretion or due to necrosis. The K19 detected in blood, on the other hand, is presumed to originate from cancer cells invading the circulatory system from a growing tumour mass. A recent paper [29] claimed that tyrosinase and cabl mRNA could be detected in filtered serum, suggesting that it was extracellular. Although such an occurrence has not been specifically discounted, immunocytochemical demonstration of K19-stained epithelial cells from peripheral blood [13] as well as their immunomagnetic capture prior to RNA extraction $[14,19]$ support the view that the detected K19 RNA is not of extracellular origin. Little is known of the half-life of free RNA in plasma. Discrepancies between K19 and CEA/CA15.3 therefore suggest either that $\mathrm{K} 19$ detection is consistently a more sensitive indicator of metastatic tumour cells or that circulating $\mathrm{K} 19+$ cells do not necessarily correlate with the presence of solid tumour deposits. A significant proportion of patients remained CEA/CA15.3- for many months after being classified $\mathrm{K} 19+$. Also notable in this context is the consistently observed low efficiency of formation of metastatic deposits resulting from circulating cells [30-33]. Studies on renal cancer and malignant ascites have shown that only a minority of postsurgical patients with an estimated $10^{9}$ circulating cancer cells developed clinical metastases after 2-3 years of follow-up [32, 33].

Circulating K19, CEA and CA15.3 in Breast Cancer
In summary, K19 signals could be detected by PCR from as few as $5-10$ cancer cells spiked in $6 \cdot 10^{6}$ lymphocytes. Random inclusion of skin cells during routine phlebotomy will generate false-positive results if sensitivity is at single-cell detection. Using a higher threshold, it was observed that $\mathrm{K} 19$ was still detected in peripheral blood at greater frequency than traditional tumor markers. Discordance with CEA/CA15.3 suggests a complex relationship between circulating cancer cells and solid tumour deposits; it remains to be seen which has more prognostic significance. ${ }^{1}$ While K19 detection seems superior, it may be clinically unnecessary/undesirable to use the assay to detect single cells. Quantitative assays using consensus primers could establish baselines and standardise measurements currently performed under diverse conditions. It may be appropriate for a shift of emphasis from designing increasingly sensitive PCRs to an analysis of the biological significance of circulating K19+ cells.

\section{Acknowledgements}

This work was supported by Project Grant NPM 031 from Research Administration, Kuwait University. We are grateful to the staff at the Haematology Department and the Oncology Clinic at the Kuwait Cancer Control Center for taking the blood samples.

1 Unfortunately, the medical records for these patients were flood damaged before the information was collected. The Cancer Center is in the process of reconstructing the files (particularly clinical follow-up, which will permit assessment of prognostic significance).

Med Principles Pract 2001;10:48-54 


\section{References}

1 Bates S: Clinical applications of serum tumour markers. Ann Intern Med 1991;115:623-638.

2 Schwartz GF, Schwarting R, Rabindranauth P et al: Clinical application of serum and markers in malignant diseases: Breast cancer as the paradigm. Clin Chem 1993;39:2404-2414.

3 Kallioniemi O, Oksa H, Aaran R, Hietenan T, Lehtinen M, Koivula T: Serum CA15-3 assay in the diagnosis and follow-up of breast cancer. Br J Cancer 1988;58:213-215.

4 Safi F, Kohler I, Rottinger E, Suhr P, Berger HG: Comparison of CA15-3 and CEA in diagnosis and monitoring of breast cancer. Int $\mathrm{J}$ Biol Markers 1989;4:207-214.

5 Vizcarra E, Lluch A, Cibrian R, Jarque F, Garcia-Conde J: CA 15.3, CEA and TPA tumor markers in the early diagnosis of breast cancer relapse. Oncology 1994;51:491-496.

6 Ballesta AM, Molina R, Filella X, Jo J, Gimenez $\mathrm{N}$ : Carcinoembryonic antigen in staging and follow-up of patients with solid tumours. Tumor Biol 1995; 16:32-41.

7 Tomlinson IPM, Whyman A, Barrett JA Kremer JK: Tumour marker CA15-3: Possible uses in the routine management of breast cancer. Eur J Cancer 1995;31A:899-902.

8 Pelkey TJ, Frierson HF, Bruns D: Molecular and immunological detection of circulating tumor cells and micrometastases from solid tumors. Clin Chem 1996;42:1369-1381.

9 Mansi JL, Easton D, Berger U, et al: Bone marrow micrometastases in primary breast cancer: Prognostic significance after 6 years follow-up. Eur J Cancer 1991;27:1552-1555.

10 Datta YH, Adams PT, Drabyski WR, Ethier SP, Terry VH, Roth MS: Sensitive detection of occult breast cancer by the reverse transcriptase polymerase chain reaction. J Clin Oncol 1994;12:475-482.

11 Brown DC, Purushotham AD, Birnie GD George WD: Detection of intraoperative tumor cell dissemination in patients with breast cancer by use of reverse transcription and polymerase chain reaction. Surgery 1995;117:96101.

12 Kruger W, Holweg M, Kruger N, et al: Reverse transcriptase/polymerase chain reaction detection of cytokeratin 19 mRNA in bone marrow and blood of breast cancer patients. J Cancer Clin Oncol 1996;122:6679-6686.
13 Schoenfeld A, Kruger KH, Gomm J, Sinnett HD, Gazet JC, Sacks N, Bender HG, Luqmani YA, Coombes RC: The detection of micrometastases in the peripheral blood and bone marrow of patients with breast cancer using immunohistochemistry and reverse transcriptase polymerase chain reaction for keratin 19. Eur J Cancer 1997;33:854-861

14 Hildebrandt M, Mapara MY, Korner IJ, Bargou RC, Moldenhauer G, Dorken B: Reverse transcriptase polymerase chain reaction (RTPCR) controlled immunomagnetic purging of breast cancer cells using the magnetic cell separation (MACS) system: A sensitive method for monitoring purging efficiency. Exp Haematol 1997;25:57-65.

15 Elthair EM, Mallinson DS, Birnie GD, Hagan C, George WD, Purushotham AD: Putative markers for the detection of breast carcinoma cells in blood. Br J Cancer 1998;77:12031207.

16 Bostick PJ, Chatterjee S, Chi DD, Huynh KT, Giuliano AE, Cote R, Hoon DSB: Limitations of specific reverse transcriptase polymerase chain reaction markers in the detection of metastases in the lymph nodes and blood of breast cancer patients. J Clin Oncol 1998;6:26323640.

17 Schoenfeld A, Luqmani YA, Smith D, et al: Detection of breast cancer micrometastases in axillary lymph nodes by using polymerase chain reaction. Cancer Res 1994;54:29862990.

18 Noguchi S, Aihara T, Motomura K, Inaji H, Imaoka S, Koyama H: Detection of breast cancer micrometastases in axillary lymph nodes by means of reverse transcriptase-polymerase chain reaction. Am J Pathol 1996;148:649656.

19 Denis MG, Lipart C, LeBorgne J, LeHur PA, Galmiche JP, Denis M, Ruud E, Truchaud A, Lustenberger P: Detection of disseminated tumor cells in peripheral blood of colorectal cancer patients. Int J Cancer (Pred Oncol) 1997; 74:540-544.

20 Aihara T, Noguchi S, Ishikawa O, Furukawa H, Hiratsuka M, Ohigashi H, Nakamori S, Monden M, Imaoka S: Detection of pancreatic and gastric cancer cells in peripheral and portal blood by amplification of keratin 19 mRNA with reverse transcriptase-polymerase chain reaction. Int J Cancer 1996;72:408-411.

21 Traweek ST, Liu J, Battifora H: Keratin gene expression in non-epithelial tissues. Detection with polymerase chain reaction. Am J Pathol 1993;142:1111-1118.
22 Savtchenko ES, Schiff TA, Jiang CK, Freedberg IM, Blumenberg M: Embryonic expression of the human $40-\mathrm{kD}$ keratin: Evidence from a processed pseudogene sequence. Am J Hum Genet 1988;43:630-637.

23 Ruud P, Fodstad O, Hovig E: Identification of a novel CK19 pseudogene, interfering with RTPCR assays in the detection of circulating tumor cells (abstract 267). Proc Am Assoc Cancer Res 1997, p 38.

24 Krismann M, Todt B, Schroder J, Gareis D, Muller KM, Seeber S, Schutte J: Low specificity of cytokeratin 19 reverse transcriptase-polymerase chain reaction analyses for detection of haematogenous lung cancer dissemination. J Clin Oncol 1995;13:2769-2775.

25 Burchill SA, Bradbury MF, Pittman K, Southgate J, Smith B, Selby P: Detection of epithelial cancer cells in peripheral blood by reverse transcriptase-polymerase chain reaction. $\mathrm{Br} \mathrm{J}$ Cancer 1995; 71:278-281.

26 Dingemans AMC, Brakenhoff RH, Postmus PE, Giaconne G: Detection of cytokeratin-19 transcripts by reverse transcriptase-polymerase chain reaction in lung cancer cell lines and blood of lung cancer patients. Lab Invest 1997; 77:213-220.

27 Chelly J, Concordet JP, Kaplan JC, Kahn A: Illegitimate transcription: Transcription of any gene in any cell type. Proc Natl Acad Sci USA 1989;86:2617-2621

28 Zach O, Kasparu H, Kreiger O, Hehenwarter W, Girschikofsky M, Lutz D: Detection of circulating mammary carcinoma cells in the peripheral blood of breast cancer patients via a nested reverse transcriptase polymerase chain reaction assay for mammoglobin mRNA. J Clin Oncol 1999;17:2015-2019.

29 Kopreski MS, Benko FA, Kwak LW, Gocke $\mathrm{CD}$ : Detection of messenger RNA in the serum of patients with malignant melanoma. Clin Cancer Res 1999;5:1961-1965.

30 Mayhew E, Glaves D: Quantitation of tumorigenic disseminating and arrested cancer cells. Br J Cancer 1984;50:159-166.

31 Tarin D, Price JE, Kettlewell MGW, Souter RG, Vass ACR, Crossley B: Mechanisms of human tumor metastases studied in patients with peritovenous shunts. Cancer Res 1984;44: 3584-3592.

32 Weiss L: Metastatic inefficiency: Causes and consequences. Cancer Rev 1986;3:1-24.

33 Glaves D, Huben RP, Weiss L: Haematogenous dissemination of cells from human adenocarcinomas. Br J Cancer 1988;57:32-35. 